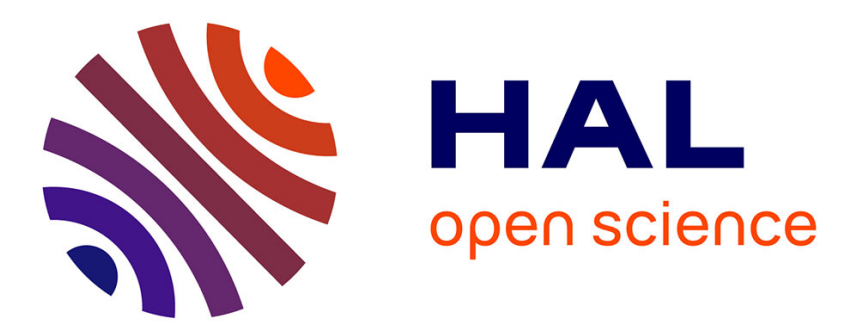

\title{
Longitudinal and Vertical Trends of Bacterial Limitation by Phosphorus and Carbon in the Mediterranean Sea
}

France van Wambeke, Urania Christaki, Antonia Giannakourou, Thierry

Moutin, K. Souvemerzoglou

\section{- To cite this version:}

France van Wambeke, Urania Christaki, Antonia Giannakourou, Thierry Moutin, K. Souvemerzoglou. Longitudinal and Vertical Trends of Bacterial Limitation by Phosphorus and Carbon in the Mediterranean Sea. Microbial ecology, 2002, 43 (1), pp.119 - 133. 10.1007/s00248-001-0038-4 . hal-01780335

\section{HAL Id: hal-01780335 \\ https://hal.science/hal-01780335}

Submitted on 15 Jun 2018

HAL is a multi-disciplinary open access archive for the deposit and dissemination of scientific research documents, whether they are published or not. The documents may come from teaching and research institutions in France or abroad, or from public or private research centers.
L'archive ouverte pluridisciplinaire HAL, est destinée au dépôt et à la diffusion de documents scientifiques de niveau recherche, publiés ou non, émanant des établissements d'enseignement et de recherche français ou étrangers, des laboratoires publics ou privés. 


\title{
Longitudinal and Vertical Trends of Bacterial Limitation by Phosphorus and Carbon in the Mediterranean Sea
}

\author{
F. Van Wambeke, ${ }^{1}$ U. Christaki, ${ }^{2}$ A. Giannakourou, ${ }^{2}$ T. Moutin, ${ }^{3}$ K. Souvemerzoglou ${ }^{2}$ \\ ${ }^{1}$ Laboratoire de Microbiologie Marine, CNRS-INSU, UMR 6117, Centre d'Océanologie de Marseille, \\ Université de la Méditerranée, Campus de Luminy, Case 907, 13288 Marseille Cedex 9, France \\ ${ }^{2}$ National Centre for Marine Research, Aghios Kosmas, 16604 Hellinikon, Greece \\ ${ }^{3}$ Laboratoire d'Océanographie et de Biogéochimie, UMR 6535, Centre d'Océanologie \\ de Marseille, Université de la Méditerranée, Campus de Luminy, Case 901, 13288 Marseille Cedex 9, France
}

Accepted: 22 August 2002; Online Publication: 23 January 2002

\section{A B S T R A C T}

The effect of phosphate $(\mathrm{P})$, nitrate $(\mathrm{N})$, and organic carbon (C, glucose) enrichment on heterotrophic bacterial production was examined along two longitudinal transects covering the whole Mediterranean Sea during June and September 1999. During these cruises, integrated bacterial production ranged from 11 to $349 \mathrm{mgC} \mathrm{m}^{-2} \mathrm{~d}^{-1}$ for the $0-150 \mathrm{~m}$ layer. $\mathrm{P}$ was found to stimulate bacterial production (BP) in 13 out of 18 experiments, in the eastern and in the western Mediterranean Sea. Organic carbon stimulation of bacterial production was observed at two stations in the Alboran Sea, where the highest bacterial production was recorded (216 and 349 $\mathrm{mg} \mathrm{C} \mathrm{m} \mathrm{d}^{-1}$ ) and in the Sicily Strait. Maximum rates of alkaline phosphatase (AP) increased from the Alboran to the Levantine Sea whereas AP turnover time decreased. Moreover, alkaline phosphatase activity was not systematically reduced following additions of $\mathrm{P}$. In cases of $\mathrm{P}$ limitation, however, the alkaline phosphatase activity to bacterial production ratio was severely reduced in the $\mathrm{P}$ and NPC enrichments. Generally, the addition of the limiting factor-whether $\mathrm{P}$ or C-had a synchronous stimulating effect on bacterial production and ectoaminopeptidase activity and induced a decline in the amino acid respiration percentage. At two selected stations in the eastern and northwestern Mediterranean, response to enrichment was tested on vertical profiles. Bacteria shifted from $\mathrm{P}$ to $\mathrm{C}$ limitation at a depth where soluble reactive phosphorus was still undetectable, but corresponding to a strong increase in alkaline phosphatase turnover time. Our results showed that values of AP turnover time lower than $100 \mathrm{~h}$ corresponded to situations of $\mathrm{P}$ limitation of bacterial production. 


\section{Introduction}

Bacteria play an important role in the flow of energy and materials through planktonic food webs. As a consequence of their high abundance, efficient nutrient uptake, and potentially rapid growth rates, bacteria may act as either a sink or a source of nutrients for higher trophic levels. Mechanisms controlling bacterial abundance and biomass have been the subject of intensive research in contemporary microbial ecology [1].

Studies on heterotrophic bacterial dynamics have shown phosphorus limitation of bacterial growth in a variety of environments $[28,37,41,46]$ and in the open ocean $[4,10,30]$. In the Mediterranean Sea, which is one of the world's most oligotrophic sea, mineral nutrients and particularly phosphorus have been shown to limit both phytoplankton and bacteria in certain areas $[6,24,35,36$, 46, 44, 45].

An interesting feature of the Mediterranean is a broad west-east gradient of oligotrophic conditions, as shown by lower primary production, [31, 40], and lower sedimentation fluxes from west to to east [26]. The increased importance of the microbial food web in the eastern Mediterranean Sea $[7,11]$ is consistent with an increase in bacterial production to primary production ratios $[3,40]$. In the eastern, relative to the western Mediterranean, there is an increasing difference between the nitracline and the phosphacline depths in stratified conditions during summer $[24,26]$, and higher N/P ratios of mineral nutrients in deeper layers reaching 20 to 25 in the Aegean Sea [39].

Although the west-east gradient of oligotrophy in the Mediterranean is often evoked [7, 11, 40], the key processes regulating the planktonic foodweb, such as nutrient control on bacterial production, transformations of dissolved organic matter, and their biochemical consequences, have not been investigated. Thus, while the problem of bacterial growth rate limitation is a very general one, the Mediterranean with its trophic gradient is an ideal place for its study. The starting point of this study was the hypothesis that there might be a gradient of nutrient limitation on heterotrophic bacterial activities, corresponding to the longitudinal decline in nutrient availability. We studied relationships between the two main indicators of P-limitation: alkaline phosphatase (AP) activity - which enables plankton to remove inorganic $\mathrm{P}$ from dissolved organic matter-and the effect of nutrient amendments (glucose, nitrate, and phosphate) on bacterial production.
In order to provide a full spatial coverage of the area, we examined these variables along two longitudinal transects in June-July and September 1999, which included a broad range of trophic conditions. We also investigated these variables down vertical profiles to assess whether there was a gradient for P-limitation in the euphotic zone. Finally, in order to test for the biogeochemical implications of nutrient limitation on the transformations of dissolved organic matter, we examined the effect of carbon and nutrient enrichments on amino acid fluxes (assimilation, respiration), and ectoenzymatic activity (phophatase, aminopeptidase).

\section{Materials and Methods}

\section{Study Sites and Sampling}

This study was carried out during the Trans Mediterranean Cruise (TMC) from June 5 to July 41999 on the RV Aegaeo, and the PROSOPE cruise from September 2 to October 41999 on the $\mathrm{RV}$ Atalante, in the framework of the EC program MATER and France-Proofs program PROSOPE, respectively. Water samples were collected from 9 (TMC) +15 (PROSOPE) stations, which were selected to represent the main basins or physical features of the Mediterranean Sea, crossing a broad gradient of oligotrophy (Fig. 1). The phytoplankton biomass during the TMC cruise ranged from 15 to $61 \mathrm{mg}$ chlorophyll $a \mathrm{~m}^{-2}$ (Pagou and Gotsis, pers comm.) and from 10 to $49 \mathrm{mg}$ chlorophyll $a \mathrm{~m}^{-2}$ during PROSOPE cruise (Ras, Marty and Claustre, pers. comm). One of the stations, located outside of the Mediterranean in the Marocco upwelling (St. UPW), was sampled as representative of eutrophic conditions (100 mg chlorophyll $a \mathrm{~m}^{-2}$, Table 1, Fig. 1). Water samples were collected using a rosette equipped with $12 \mathrm{~L}$ Niskin bottles around noon.

\section{Nutrients}

Water samples for the determination of nitrite and nitrate were collected in $100 \mathrm{ml}$ polyethylene bottles and kept frozen $\left(-20^{\circ} \mathrm{C}\right)$ until analysis in the laboratory. Nitrate and nitrite were analyzed by a Bran+Luebbe Autoanalyzer II, according to the procedure of Treguer and Le Corre [38]. The precision is estimated at \pm 0.05 $\mu \mathrm{M}$ for nitrate and $\pm 0.02 \mu \mathrm{M}$ for nitrite.

Soluble reactive phosphorus was measured according to the method of Murphy and Riley [27]. During the TMC cruise, samples were analyzed on board with a Perkin Elmer Lambda $2 S$ UV/VIS Spectrophotometer. The precision and detection limits of this method were $20 \mathrm{nM}$. During the PROSOPE cruise, soluble reactive $\mathrm{P}$ was analyzed after a 6 -fold concentration step following the magnesium-induced coprecipitaion (MAGIC) procedure [20], which brings the detection limits down to $5 \mathrm{nM}$. To avoid contamination, only one bottle (polycarbonate, $60 \mathrm{ml}$ ) was 


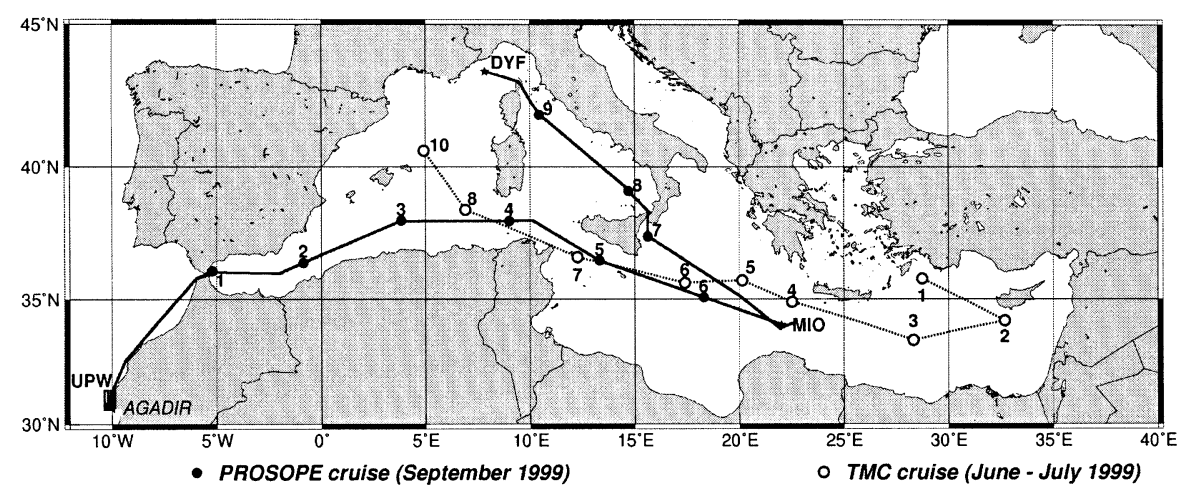

Fig. 1. TMC (June 1999) and PROSOPE (September 1999) cruise tracks with stations. Note that one station is located outside the Mediterranean, in the Marocco upwelling (St UPW) as representative of eutrophic conditions, while DYF (Dyfamed station, Ligurian Sea) and MIO (Ionian Sea) stations in Mediterranean were chosen to correspond to mesotrophic and highly oligotrophic conditions, respectively. used for sampling, centrifugation, precipitate treatment, and analysis. Spectrophotometric analysis was performed with a CECIL CE 1011 spectrophotometer using a cell with a long optical length $(10 \mathrm{~cm})$ and small volume $(10 \mathrm{ml})$. With this method precision was $\pm 3 \mathrm{nM}$. Dissolved and particulate organic phosphorus was determined using the persulfate wet-oxidation method [42].

\section{Bioassays}

Response of the bacteria to nutrient and/or carbon addition was examined in 15 experiments in the subsurface layer (TMC cruise, stations TM-01, -03, -06, -07, -08, and -10; PROSOPE Cruise, stations PRO-1 to PRO-9). During the PROSOPE cruise, enrichment experiments on vertical profiles were performed at three stations representative of eutro-, meso-, and oligotrophic conditions, abbreviated UPW (Marocco upwelling), MIO (Ionian Sea) and DYF (Dyfamed station, Ligurian Sea, Fig. 1).

Table 1. Station location

\begin{tabular}{cllcrc}
\hline & Station & Date & lat. & Long. & Depth $(\mathrm{m})$ \\
\hline TMC & TM-01 & $7 / 6 / 99$ & $35^{\circ} 78 \mathrm{~N}$ & $28^{\circ} 69 \mathrm{E}$ & 3800 \\
cruise & TM-02 & $10 / 6 / 99$ & $34^{\circ} 15 \mathrm{~N}$ & $32^{\circ} 67 \mathrm{E}$ & 2695 \\
& TM-03 & $14 / 6 / 99$ & $33^{\circ} 39 \mathrm{~N}$ & $28^{\circ} 29 \mathrm{E}$ & 3082 \\
& TM-04 & $16 / 6 / 99$ & $34^{\circ} 89 \mathrm{~N}$ & $22^{\circ} 53 \mathrm{E}$ & 2982 \\
& TM-05 & $18 / 6 / 99$ & $35^{\circ} 70 \mathrm{~N}$ & $20^{\circ} 15 \mathrm{E}$ & 3150 \\
& TM-06 & $20 / 6 / 99$ & $35^{\circ} 62 \mathrm{~N}$ & $17^{\circ} 39 \mathrm{E}$ & 4032 \\
& TM-07 & $23 / 6 / 99$ & $36^{\circ} 61 \mathrm{~N}$ & $12^{\circ} 24 \mathrm{E}$ & 1313 \\
& TM-08 & $27 / 6 / 99$ & $38^{\circ} 40 \mathrm{~N}$ & $6^{\circ} 89 \mathrm{E}$ & 2854 \\
& TM-10 & $1 / 7 / 99$ & $40^{\circ} 58 \mathrm{~N}$ & $4^{\circ} 95 \mathrm{E}$ & 2756 \\
PROSOPE & UPW & $10 / 09 / 99$ & $31^{\circ} 00 \mathrm{~N}$ & $10^{\circ} 01 \mathrm{~W}$ & 100 \\
cruise & PRO-1 & $14 / 09 / 99$ & $36^{\circ} 05 \mathrm{~N}$ & $5^{\circ} 11 \mathrm{~W}$ & 775 \\
& PRO-2 & $15 / 09 / 99$ & $36^{\circ} 24 \mathrm{~N}$ & $0^{\circ} 51 \mathrm{~W}$ & 2556 \\
& PRO-3 & $16 / 09 / 99$ & $37^{\circ} 59 \mathrm{~N}$ & $3^{\circ} 50 \mathrm{E}$ & 2704 \\
& PRO-4 & $17 / 09 / 99$ & $37^{\circ} 59 \mathrm{~N}$ & $8^{\circ} 31 \mathrm{E}$ & 2292 \\
& PRO-5 & $18 / 09 / 99$ & $36^{\circ} 28 \mathrm{~N}$ & $13^{\circ} 19 \mathrm{E}$ & 1688 \\
& PRO-6 & $19 / 09 / 99$ & $35^{\circ} 04 \mathrm{~N}$ & $18^{\circ} 17 \mathrm{E}$ & 3699 \\
& MIO & $21 / 09 / 99$ & $33^{\circ} 58 \mathrm{~N}$ & $22^{\circ} 02 \mathrm{E}$ & 2112 \\
& PRO-7 & $26 / 09 / 99$ & $37^{\circ} 23 \mathrm{~N}$ & $15^{\circ} 36 \mathrm{E}$ & 2096 \\
& PRO-8 & $27 / 09 / 99$ & $39^{\circ} 06 \mathrm{~N}$ & $14^{\circ} 42 \mathrm{E}$ & 3288 \\
& PRO-9 & $28 / 09 / 99$ & $41^{\circ} 53 \mathrm{~N}$ & $10^{\circ} 26 \mathrm{E}$ & 1051 \\
& DYF & $30 / 09 / 99$ & $43^{\circ} 24 \mathrm{~N}$ & $7^{\circ} 51 \mathrm{E}$ & 2280 \\
\hline
\end{tabular}

Seawater samples $(250 \mathrm{ml}$ during TMC cruise, $40 \mathrm{ml}$ during PROSOPE cruise) were poured into five Nalgene acid-cleaned polycarbonate bottles. $\mathrm{NaNO}_{3}, \mathrm{Na}_{2} \mathrm{HPO}_{4}$, and D-glucose were added to give final concentrations as follows: Co (control) was unamended, $\mathrm{N}$ received $2 \mu \mathrm{M}$ nitrate solution, $\mathrm{P}$ received $0.25 \mu \mathrm{M}$ phosphate solution, C received $1.66 \mu \mathrm{M}$ glucose (i.e. $10 \mu \mathrm{M}$ glucose-C) solution, and NPC received all three components. The corresponding stochiometric atomic ratios were $\mathrm{C} / \mathrm{N}=5$ and $\mathrm{N} / \mathrm{P}=8$. After adding the nutrients, the bottles were placed in an on-deck incubator with circulating surface seawater and covered with a neutral screen providing 50\% incident light. Following 24 $\mathrm{h}$ incubation, subsamples were removed from each bottle for bacterial production measurements. Samples for bacterial abundance, amino acid fluxes, and ectoaminopeptidase and phosphatase activity were also taken at stations TM-03, $-06,-07$, -08 , and -10 during the TMC cruise.

Reproductibility tests run on three occasions in the eastern and western basins showed that the coefficient of variation of bacterial production response within triplicate bottles was on average $17 \%$ (max. $25 \%$ ). Variability within triplicates for ${ }^{14} \mathrm{C}$ methodology (used for amino acid uptake rates and respiration) was higher, averaging $20 \%$, whereas for potential ectoaminopeptidase activity it was lower, averaging $6 \%$.

\section{Bacterial Abundance}

Water samples for bacteria, Synechococcus-like cyanobacteria, and heterotrophic and autotrophic nanoflagellates were preserved with tetraborate-buffered formalin ( $2 \%$ final concentration). Within $24 \mathrm{~h}$, samples were filtered and stained with DAPI, and the slides were stored frozen until they could be counted using epifluorescence microscopy as described in Christaki et al. [6].

\section{Bacterial Production}

Bacterial production was estimated using ${ }^{3} \mathrm{H}$-leucine. The classical filtration method was used during the TMC cruise [22, 43] whereas the centrifugation method [34] was used during the PROSOPE cruise. During the TMC cruise, $10 \mathrm{ml}$ duplicates were amended with $1 \mathrm{nM}\left[4,5-{ }^{3} \mathrm{H}\right]$ leucine (Amersham, $141 \mathrm{Ci} \mathrm{mmol}^{-1}$ ) 
and $19 \mathrm{nM}$ unlabeled leucine. A third sample was killed with 1\% formalin prior to isotope addition and was used as the control. Samples were incubated in the dark at the ambient temperature of the depth of collection $\left( \pm 1^{\circ} \mathrm{C}\right)$ for $2 \mathrm{~h}$, which was tested to satisfy linear incorporation with time. The incubations were stopped using formalin ( $1 \%$ final concentration). The samples were then filtered through $0.2 \mu \mathrm{m}$ cellulose ester filters (Millipore type GS), extracted and rinsed three times with $5 \%$ trichloracetic acid (TCA) and stored frozen. Filters were later dissolved with $0.5 \mathrm{ml}$ ethyl acetate prior to the addition of $10 \mathrm{ml}$ of PCS Amersham Scintillation cocktail.

During the PROSOPE cruise, $1.5 \mathrm{ml}$ samples were dispensed into $2 \mathrm{ml}$ screw cap microcentrifuge tube. A mixture of $\left[4,5-{ }^{3} \mathrm{H}\right]$ leucine (Amersham, $155 \mathrm{Ci} \mathrm{mmol}^{-1}$ ) and nonradioactive leucine was added to final concentrations of 16 and $4 \mathrm{nM}$, respectively. Samples were incubated like in the filtration method. Incubations were stopped by the addition of 50\% TCA to give a final concentration of $5 \%$ TCA. Fifty $\mu \mathrm{l}$ of a bovine serum albumin (BSA, Sigma) solution was added to facilitate precipitation of the proteins (final concentration $100 \mathrm{mg}$ BSA $\mathrm{l}^{-1}$ ). The samples were centrifuged at $16,000 \mathrm{~g}$ for $10 \mathrm{~min}$. The supernatant was discarded and $1.5 \mathrm{ml}$ of 5\% TCA was added. The samples were shaken vigorously using a vortex mixer and centrifuged again. The supernatent was discarded and $1.5 \mathrm{ml}$ of PCS scintillation cocktail (Amersham) was added. Radioactivity was analyzed by a Packard LS 1600 Liquid Scintillation Counter.

Bacterial production values in samples treated with BSA addition were on average $96 \pm 13 \%(n=21)$ of those obtained with the filtration technique, and $73 \pm 9 \%$ of the values obtainedwithout the BSA addition [34]. Concentration kinetic experiments showed that isotopic dilution was negligible for the $20 \mathrm{nM}$ leucine additions used during both cruises. We thus used a conversion factor equal to 1 , yielding $1.5 \mathrm{~kg} \mathrm{C}$ per mole leucine incorporated [22].

\section{Alkaline Phosphatase Activity}

Alkaline-phosphatase (AP) activity was measured fluorometrically using methylumbelliferone phosphate (MUF-P [17]). Stock solutions of $5 \mathrm{mM}$ in methylcellosolve were stored at $-20^{\circ} \mathrm{C}$ and diluted with boiled-filtered seawater prior to use. The linear increase in fluorescence in seawater with added MUF-P was measured over $9 \mathrm{~h}$ (excitation at $365 \mathrm{~nm}$ and emission at $460 \mathrm{~nm}$ ) with a Hitachi F-2000 spectrofluorometer during the TMC cruise and on a Kontron SFM 23B during the PROSOPE cruise. Calibration curves were made with MUF standards. The kinetic coefficients were determined using a range of concentrations of MUF-P from 25 to $1000 \mathrm{nM}$, which is reasonable considering the dissolved and particulate organic phosphorus concentrations that were measured during the PROSOPE cruise (excluding station UPW, 160-265 $\mathrm{nM}$ and 4.2-45 nM, respectively). The following transformation of the Michaelis-Menten equation was used to determine kinetic coefficients:

$$
\mathrm{S} / \mathrm{V}=(\mathrm{K}+\mathrm{Sn}) / \mathrm{Vm}+\mathrm{S} / \mathrm{Vm}
$$

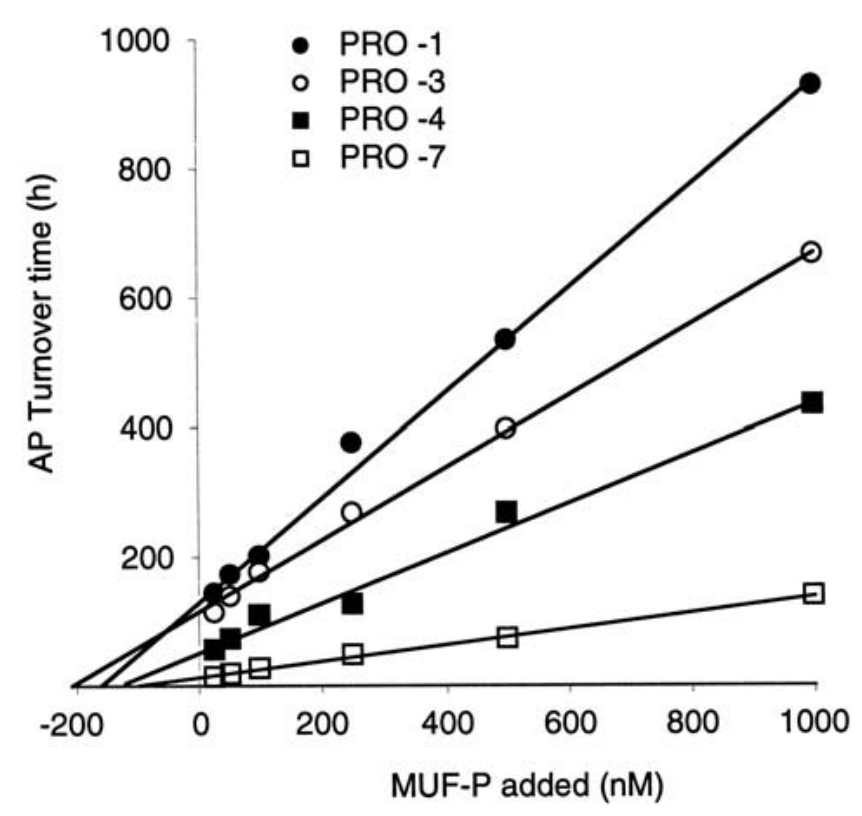

Fig. 2. Alkaline phosphatase (AP). Concentration dependence of turnover time, for stations PRO-1 (5m), PRO-3 (18m) PRO-4 $(21 \mathrm{~m})$ and PRO-7 (35m). Fitted regression lines are shown.

where $\mathrm{S}$ is the MUF-P concentration and $\mathrm{V}$ the hydrolysis rate. Plotting S/V ratio versus $S$ resulted in a straight line from which the maximum hydrolysis rate $\mathrm{Vm}\left(\mathrm{nM} \mathrm{h}^{-1}\right)$ is the inverse of the slope and the sum of the half saturation constant plus the natural concentration $\mathrm{K}+\mathrm{Sn}(\mathrm{nM})$ is the $x$-axis intercept (Fig. 2) and the turnover time is the $\mathrm{y}$-axis intercept (expressed in $\mathrm{h}$ ):

$$
\text { Turnover time }=(\mathrm{K}+\mathrm{Sn}) / \mathrm{Vm}
$$

For depth profiles, we did not perform concentration kinetic experiments and thus neither Vm of AP nor $\mathrm{K}+\mathrm{Sn}$ (Eq. 1) values were measured. Alkaline phosphatase activity was measured along MIO and DYF profiles with only one concentration of added MUF-P (25 nM). From a comparison made on surface layers of the stations of the transect with turnover times ranging 14 to $182 \mathrm{~h}$, we estimated that the turnover time measured with 25 nM MUF-P additions was only $5 \%$ higher than the value obtained from concentration kinetics $(n=11$, slope $=1.05 \pm 0.01, r=0.99)$. This $5 \%$ difference is close to the error of a turnover time estimated with a concentration kinetic (Table 1) and thus, on depth profiles, we assumed that the turnover times are reasonably correct. From Eq.(2), Vm can be calculated from the turnover time and an estimate of $\mathrm{K}+\mathrm{Sn}$, as discussed in the results section.

Alkaline phosphatase activity (with $0.25 \mu \mathrm{M}$ MUF-P addition) was also measured on the bioassays processed at stations TM-03, $-06,-07,-08$, and -10 .

\section{Ectoaminopeptidase Activity}

The ectoenzymatic aminopeptidase activity was estimated by measuring the hydrolysis rate of L-leucine-4-methyl-7-coumarinylamide (leu-MCA, Sigma), which is used as an analog substrate 
for natural peptides [17]. Stock solutions of $10 \mathrm{mM}$ leu-MCA were prepared in methylcellosolve and kept at $-20^{\circ} \mathrm{C}$. Potential ectoaminopeptidase activity was measured with a substrate addition of $200 \mu \mathrm{M}$. This concentration represented the saturation level as determined with preliminary concentration kinetics. The increase of fluorescence was measured with the excitation set at $380 \mathrm{~nm}$ and the emission at $440 \mathrm{~nm}$. Incubation was performed at in situ temperature in the dark. Blanks were run by adding the leu-MCA to filtered boiled seawater and were shown to be unsignificant. Relative fluorescence units were calibrated with 4 methyl-coumarin standards. Potential ectoaminopeptidase activity (PEA, expressed in nmol leu hydrolyzed $\mathrm{L}^{-1} \mathrm{~h}^{-1}$ ) was measured along the surface layers studied for the longitudinal transects and on the bioassays processed at stations TM-03, $-06,-07,-08$, and -10 .

In order to estimate the size distribution of bacterial activity, a size fractionation experiment was performed at station DYF for a $15 \mathrm{~m}$ water sample. Reverse filtration with in a Teflon apparatus without vaccuum was used [2]. Bacterial production, alkaline phosphatase activity, and ectoaminopeptidase activity were measured in each fraction: total, $<2 \mu \mathrm{m},<0.6 \mu \mathrm{m}$, and $<\mathrm{GF} / \mathrm{F}$ (glass fiber filter) in triplicate.

\section{Amino Acid Uptake and Respiration}

Potential assimilation rates and percentage of respiration of amino acids (PAA and \% resp, respectively) were measured in subsamples taken from the bioassays, $24 \mathrm{~h}$ after enrichments, at stations TM-03, $-06,-07,-08$, and -10 . PAA and \% resp were measured by adding a mixture of ${ }^{14} \mathrm{C}$-amino acids at saturating substrate concentrations (final concentration of $200 \mathrm{nM}$ ) to $20 \mathrm{ml}$ duplicates and a formalin killed control. The ${ }^{14} \mathrm{C}$ amino acid mixture (Amersham, $52 \mathrm{mCi}$ mmole $\mathrm{C}^{-1}$ ) included 16 amino acids, and their individual proportion (by activity) ranged from 0.6 (meth) to $13 \%$ (leu). Samples were incubated for 2 hours at in situ temperature in the dark and incubation was stopped by the addition of formalin ( $1 \%$ final concentration) buffered with sodium tetraborate. Following fixation, the samples were filtered through $0.2 \mu \mathrm{m}$ polycarbonate Nuclepore filters, which were then rinsed 3 times with $0.2 \mu \mathrm{m}$ filtered seawater.

The filtrates were acidified $(200 \mu \mathrm{l} \mathrm{HCl}, 6 \mathrm{~N})$ and the released ${ }^{14} \mathrm{C}_{-}-\mathrm{CO}_{2}$ was flushed using $\mathrm{N}_{2}\left(100 \mathrm{ml} \mathrm{min}{ }^{-1}\right)$ for $10 \mathrm{~min} . \mathrm{CO}_{2}$ was trapped in two successive scintillation vials each containing 9 $\mathrm{ml}$ of a cocktail of ethanolamine-methanol-scintillation liquid (PCS, Amersham) in a ratio $1: 1: 7 \mathrm{v} / \mathrm{v}$ [13] and counted on a Packard 1600 TR scintillation counter.

\section{Results}

Water Column Structure and Trophic Gradient

In June-July, mixed layer depths at the stations investigated ranged from 6 to $25 \mathrm{~m}$ (Table 2). The lowest values of bacterial production and nutrients were measured in the Irapetra anticyclonic gyre in the Levantine basin (Table 2; stations TM-02 and TM-03). At these two sta-

Table 2. Main characteristics of the stations (depth of the mixed layer, depth of the chlorophyll maximum (CHL MAX), depth of the $50 \mathrm{nM}$ soluble reactive phosphorus (SRP) level

\begin{tabular}{|c|c|c|c|c|c|c|}
\hline & Station & $\begin{array}{l}\text { Mixed layer } \\
\text { depth (m) }\end{array}$ & $\begin{array}{l}\text { Chl max } \\
\text { depth (m) }\end{array}$ & $\begin{array}{c}0-150 \mathrm{~m} \text { IBP } \\
\left(\mathrm{mg} \mathrm{C} \mathrm{m}^{-2} \mathrm{~d}^{-1}\right)\end{array}$ & $\begin{array}{c}0-150 \mathrm{~m} \mathrm{I}-\mathrm{SRP} \\
\left(\mathrm{mmol} \mathrm{m}^{-2}\right)\end{array}$ & $\begin{array}{l}\text { Depth of } 50 \mathrm{nM} \\
\text { SRP }(\mathrm{m})\end{array}$ \\
\hline \multirow[t]{9}{*}{ TMC cruise } & TM-01 & 12 & 115 & 24.5 & 6.5 & 128 \\
\hline & TM-02 & 8 & 140 & 11.4 & 3.3 & 264 \\
\hline & TM-03 & 15 & 135 & 16.4 & 3.2 & 228 \\
\hline & TM-04 & 10 & 90 & 29.8 & 5.4 & 127 \\
\hline & TM-05 & 12 & 65 & 35.2 & 6.7 & 114 \\
\hline & TM-06 & 6 & 95 & 18.7 & 3.4 & 220 \\
\hline & TM-07 & 25 & 95 & 50.4 & 4.4 & 122 \\
\hline & TM-08 & 15 & 70 & 70.7 & 15.3 & 58 \\
\hline & TM-10 & 20 & 62 & 72.1 & 7.8 & 106 \\
\hline \multirow[t]{12}{*}{ PROSOPE cruise } & UPW & 5 & 10 & $394^{\mathrm{b}}$ & $63.0^{\mathrm{b}}$ & $\operatorname{surf}^{c}$ \\
\hline & PRO-1 & 5 & $25 \& 60$ & 349 & 26.8 & 57 \\
\hline & PRO-2 & 15 & 45 & 216 & 25.2 & 42 \\
\hline & PRO-3 & 18 & $55 \& 95$ & 121 & 12.1 & 41 \\
\hline & PRO-4 & 21 & 75 & 49.2 & 12.3 & 76 \\
\hline & PRO-5 & 15 & $55 \& 65$ & 71.3 & 8.9 & 77 \\
\hline & PRO-6 & 31 & 95 & 52.6 & 3.9 & 155 \\
\hline & MIO & 30 & 95 & 62.6 & 2.1 & 171 \\
\hline & PRO-7 & 35 & 70 & 68.8 & 3.1 & 157 \\
\hline & PRO-8 & 20 & 70 & 53.2 & 5.9 & 112 \\
\hline & PRO-9 & 18 & 65 & 56.2 & 9.8 & 91 \\
\hline & DYF & 20 & 45 & 76.5 & 21.4 & 63 \\
\hline
\end{tabular}

${ }^{\mathrm{a}}$ Integrated bacterial production (IBP), integrated SRP (I-SRP).

${ }^{\mathrm{b}} \mathrm{UPW}$ station was integrated $0-90 \mathrm{~m}$.

${ }^{c}$ for UPW all SRP concentrations were $>100 \mathrm{nM}$. 
tions, the chlorophyll maximum was recorded at 140 and $135 \mathrm{~m}$ while a concentration of $50 \mathrm{nM}$ of soluble reactive $\mathrm{P}$ was recorded at 264 and $228 \mathrm{~m}$, respectively. Bacterial production ranged from 11.4 (TM-02) to 72.1 (TM-10, $4.95^{\circ} \mathrm{E}$, North of Balearic Islands) $\mathrm{mg} \mathrm{C} \mathrm{m}^{-2} \mathrm{~d}^{-1}$, and integrated soluble reactive $P$ ranged 3.3 to $15.3 \mathrm{mmol} \mathrm{m}^{-2}$.

In September, the depth of the mixed layer varied from 5 to $35 \mathrm{~m}$. The chlorophyll maximum depth increased from the west $\left(10^{\circ} \mathrm{W}\right)$ to the east $\left(22^{\circ} \mathrm{E}\right)$ from 25 to $95 \mathrm{~m}$. Integrated soluble reactive $\mathrm{P}$ decreased from 26.8 to 2.1 $\mathrm{mmol} \mathrm{m} \mathrm{m}^{-2}$ from west to east and the depth where $50 \mathrm{nM}$ soluble reactive $\mathrm{P}$ was reached deepened from 40 to $170 \mathrm{~m}$. In the Thyrrenian Sea (stations MIO to DYF, Fig. 1), the integrated soluble reactive $\mathrm{P}$ remained low $(2-6 \mathrm{mmol}$ $\mathrm{m}^{-2}$ ), with slightly higher values at the North Thyrrhenian Sea (PRO-9) and DYF Stations (10 and $21 \mathrm{mmol}$ soluble reactive $\mathrm{P} \mathrm{\textrm {m } ^ { - 2 }}$, respectively). Bacterial production decreased from 349 to $59 \mathrm{mg} \mathrm{C} \mathrm{m}^{-2} \mathrm{~d}^{-1}$ from the east to the central Mediterranean (from PRO-1 to PRO-6, Fig. 1) and increased along the Thyrrhenian sea transect up to $76 \mathrm{mg}$ $\mathrm{C} \mathrm{m} \mathrm{m}^{-2} \mathrm{~d}^{-1}$ (DYF station). The eutrophic status of the station UPW in the Maroco upwelling was evident from the high values of integrated soluble reactive $\mathrm{P}(63 \mathrm{mmol}$ $\mathrm{m}^{-2}$ ) and bacterial production (394 $\mathrm{mg} \mathrm{C} \mathrm{m}^{-2} \mathrm{~d}^{-1}$ ), which were clearly out of the range of values measured in the Mediterranean.

Combining all the data from the Mediterranean stations (i.e., excluding the station UPW), integrated bacterial production correlated with chlorophyll $(r=0.51, p<0.05)$ and with soluble reactive $\mathrm{P}(r=0.73, p<0.001)$ whereas correlation was insignificant between chlorophyll and soluble reactive $\mathrm{P}(r=0.3, p>0.05)$.

\section{Environmental and Biological Variables in Surface Layer}

During both cruises, soluble reactive $\mathrm{P}$ concentrations in the surface layer were undetectable (excluding UPW station). The sum of nitrate + nitrite ranged from 0.18 to 0.45 $\mu \mathrm{M}$ in June and 0.03 to $0.14 \mu \mathrm{M}$ in September.

The number of Synechococcus-like cyanobacteria increased from the east to the west Mediterranean Sea during both cruises, with slightly higher abundances in September (from 2.9 to $13 \times 10^{3} \mathrm{ml}^{-1}$ and from 9.6 to $85 \times$ $10^{3} \mathrm{ml}^{-1}$, respectively; Table 3 ). Excluding the UPW station outside the Mediterranean, phototrophic nanoflagellates, heterotrophic nanoflagellates and bacterial abundances varied 5-fold ( 0.4 to $2.2 \times 10^{3} \mathrm{ml}^{-1}, 0.5$ to $2.3 \times$ $10^{3} \mathrm{ml}^{-1}$, and 2.4 to $10.7 \times 10^{5} \mathrm{ml}^{-1}$, respectively; Table 3 ).

Table 3. Biological variables at the depths sampled for bioassays and/or APA kinetics

\begin{tabular}{|c|c|c|c|c|c|c|c|c|c|c|}
\hline & Station & $\begin{array}{l}\text { Depth } \\
\text { (m) }\end{array}$ & $\begin{array}{l}\text { TEMP } \\
\left({ }^{\circ} \mathrm{C}\right)\end{array}$ & $\begin{array}{l}\text { SAL } \\
\text { (PSU) }\end{array}$ & $\underset{\mathrm{mL}^{-1}}{\mathrm{CYANO} \times 10^{3}}$ & $\underset{\mathrm{mL}^{-1}}{\mathrm{PNAN} \times 10^{3}}$ & $\underset{\mathrm{mL}^{-1}}{\mathrm{HNAN} \times 10^{3}}$ & $\begin{array}{l}\mathrm{NB} \times 10^{5} \\
\mathrm{~mL}^{-1}\end{array}$ & BP ngCL ${ }_{h^{-1}}^{-1}$ & $\begin{array}{l}\text { PEA nmol } \\
\mathrm{L}^{-1} \mathrm{~h}^{-1}\end{array}$ \\
\hline \multirow{9}{*}{$\begin{array}{l}\text { TMC } \\
\text { cruise }\end{array}$} & TM-01 & 3 & 22.7 & 39.01 & 4.3 & 0.94 & 0.77 & 2.68 & 10.0 & 1.1 \\
\hline & TM-02 & 3 & 24.2 & 38.94 & 3.6 & 0.64 & 0.51 & 2.81 & 21.7 & 6.1 \\
\hline & TM-03 & 3 & 22.9 & 38.76 & 2.9 & 0.59 & 0.65 & 2.38 & 15.6 & 4.6 \\
\hline & TM-04 & 3 & 23.9 & 38.60 & 4.6 & 0.89 & 1.00 & 2.6 & 14.5 & 5.2 \\
\hline & TM-05 & 3 & 24.9 & 38.59 & 4.4 & 1.03 & 0.84 & 2.72 & 18.8 & 4.4 \\
\hline & TM-06 & 3 & 24.5 & 38.54 & 4.1 & 0.72 & 1.09 & 2.71 & 16.8 & 5.2 \\
\hline & TM-07 & 3 & 21.3 & 37.28 & 11.0 & 1.05 & 1.27 & 5.72 & 26.9 & 6.8 \\
\hline & TM-08 & 3 & 22.2 & 37.44 & 13.0 & 1.05 & 1.64 & 5.73 & 40.1 & 6.0 \\
\hline & TM-10 & 4 & 22.7 & 37.49 & 7.7 & 1.99 & 0.82 & 5.50 & 33.7 & 9.3 \\
\hline \multirow{12}{*}{$\begin{array}{l}\text { PROSOPE } \\
\text { cruise }\end{array}$} & UPW & 16 & 16.5 & 36.11 & 6.7 & 2.20 & 2.47 & 14.9 & 1153 & 70 \\
\hline & PRO-1 & 11 & 20.3 & 36.69 & 84.8 & 1.16 & 1.03 & 10.7 & 110.8 & 15.1 \\
\hline & PRO-2 & 15 & 24.2 & 36.78 & 40.3 & 0.76 & 1.65 & 7.68 & 74.6 & 12.8 \\
\hline & PRO-3 & 10 & 25.4 & 36.77 & 21.9 & 0.75 & 0.51 & 7.64 & 65 & 10.6 \\
\hline & PRO-4 & 13 & 25.5 & 37.86 & 12.3 & 0.40 & 1.27 & 5.85 & 34.8 & 8.6 \\
\hline & PRO-5 & 11 & 24.5 & 37.93 & 16.1 & 0.51 & 1.03 & 6.68 & 43.8 & 5.4 \\
\hline & PRO-6 & 10 & 27.4 & 38.64 & 9.6 & 0.72 & 1.13 & 4.45 & 30.1 & 7.8 \\
\hline & MIO & 15 & 25.8 & 38.89 & 10.7 & 0.67 & 1.36 & 4.61 & 29.1 & 5.0 \\
\hline & PRO-7 & 14 & 25.6 & 38.53 & 19.8 & 0.61 & 1.17 & 5.29 & 40.6 & 8.2 \\
\hline & PRO-8 & 15 & 25.3 & 38.02 & 21.9 & 0.68 & 1.33 & 7.33 & 24.9 & 14.1 \\
\hline & PRO-9 & 15 & 23.4 & 38.14 & 16.4 & 1.19 & 2.01 & 6.20 & 41.2 & 9.9 \\
\hline & DYF & 10 & 22.3 & 38.32 & 47.2 & 1.13 & 2.27 & 8.21 & 42 & 10.1 \\
\hline
\end{tabular}


Bacterial production varied 10 fold, from 10 to $110 \mathrm{ng} \mathrm{C}$ $\mathrm{L}^{-1} \mathrm{~h}^{-1}$, whereas surface water temperature ranged from 20 to $27^{\circ} \mathrm{C}$ (Table 3 ). Potential ectoaminopeptidase activity was $1.1 \mathrm{nmol} \mathrm{L}{ }^{-1} \mathrm{~h}^{-1}$ at station TM-01 and $9.3 \mathrm{nmol} \mathrm{L}-1$ $\mathrm{h}^{-1}$ at station TM-10, but there was not a clear eastwest gradient (mean $5.4 \pm 0.8 \mathrm{nmol} \mathrm{L}{ }^{-1} \mathrm{~h}^{-1}$ for stations TM-02 to TM-08). In September, values ranged from 5 to $14 \mathrm{nmol} \mathrm{L}^{-1} \mathrm{~h}^{-1}$; decreasing from the Gibraltar Strait to station MIO and increasing again toward station DYF. The outlying status of the UPW station was characterized by most variables: lower temperature, higher abundances of flagellates (both auto and heterotrophs), bacteria, bacterial production, and aminopeptidase activities.

\section{In Situ Kinetics of Alkaline Phosphatase Activity}

Turnover time of alkaline phosphatase (AP) decreased from the west to the east Mediterranean, i.e., from $182 \mathrm{~h}$ at station PRO-2 to $11 \mathrm{~h}$ at station PRO-7, whereas it reached $786 \mathrm{~h}$ at station UPW (Table 4). Maximum rates of AP ranged from 0.62 to $12 \mathrm{nmol} \mathrm{L}^{-1} \mathrm{~h}^{-1}$, including a value of $1.1 \mathrm{nmol} \mathrm{L}^{-1} \mathrm{~h}^{-1}$ at station UPW. K+ Sn (Eq. 1) ranged from 76 to $206 \mathrm{nM}$ in the Mediterranean surface samples and reached $848 \mathrm{nM}$ at station UPW. $\mathrm{K}+\mathrm{Sn}$ values of AP activity varied to a much lesser degree than AP maximum rates (Table 4). We computed a mean $\mathrm{K}+\mathrm{Sn}$ of $96 \pm 13 \mathrm{nM}$ for stations PRO-5 to PRO-9 and a mean of $183 \pm 20 \mathrm{nM}$ for stations PRO-1 to PRO-3.

Table 4. Kinetic parameters of alkaline phosphatase. ${ }^{a}$ TT: turnover time, Vm: maximum velocity, $\mathrm{K}+\mathrm{Sn}$ : $\mathrm{X}$ intercept of the regression (see Methods).

\begin{tabular}{|c|c|c|c|c|c|}
\hline & Station & $\begin{array}{l}\text { Depth } \\
\text { (m) }\end{array}$ & TT (h) & $\begin{array}{c}\mathrm{Vm}(\mathrm{nmol} \\
\left.\mathrm{L}^{-1} \mathrm{~h}^{-1}\right)\end{array}$ & $\begin{array}{c}\mathrm{K}+\mathrm{Sn} \\
(\mathrm{nM})\end{array}$ \\
\hline \multirow{3}{*}{$\begin{array}{l}\text { TMC } \\
\text { cruise }\end{array}$} & TM-02 & 3 & $84 \pm 9$ & $1.65 \pm 0.05$ & $139 \pm 18$ \\
\hline & TM-04 & 3 & $31 \pm 5$ & $3.0 \pm 0.2$ & $91 \pm 25$ \\
\hline & TM-07 & 3 & $121 \pm 26$ & $0.62 \pm 0.02$ & $76 \pm 18$ \\
\hline \multirow{12}{*}{$\begin{array}{l}\text { PROSOPE } \\
\text { cruise }\end{array}$} & UPW & 15 & $786 \pm 61$ & $1.1 \pm 0.2$ & $848 \pm 165$ \\
\hline & PRO-1 & 11 & $135 \pm 13$ & $1.25 \pm 0.04$ & $168 \pm 21$ \\
\hline & PRO-2 & 15 & $182 \pm 17$ & $0.96 \pm 0.03$ & $175 \pm 20$ \\
\hline & PRO-3 & 10 & $114 \pm 6$ & $1.80 \pm 0.04$ & $206 \pm 15$ \\
\hline & PRO-4 & 12 & $51 \pm 10$ & $2.6 \pm 0.2$ & $133 \pm 31$ \\
\hline & PRO-5 & 11 & $52 \pm 8$ & $1.63 \pm 0.04$ & $86 \pm 14$ \\
\hline & PRO-6 & 10 & $31 \pm 3$ & $2.60 \pm 0.04$ & $83 \pm 8$ \\
\hline & MIO & 15 & $27 \pm 4$ & $4.0 \pm 0.1$ & $111 \pm 16$ \\
\hline & PRO-7 & 14 & $11 \pm 1$ & $7.91 \pm 0.09$ & $88 \pm 6$ \\
\hline & PRO-8 & 15 & $21 \pm 2$ & $4.57 \pm 0.08$ & $95 \pm 9$ \\
\hline & PRO-9 & 15 & $19 \pm 2$ & $5.9 \pm 0.2$ & $114 \pm 13$ \\
\hline & DYF & 10 & $14 \pm 1$ & $12.6 \pm 0.3$ & $178 \pm 13$ \\
\hline
\end{tabular}

Response to Enrichment

Longitudinal Trends. Bacterial numbers for the enrichment experiments during the TMC cruise revealed no significant increase in the unamended control after $24 \mathrm{~h}$ incubation. Some increase in bacterial abundance was observed in P and C amended bottles at TM-06 (1.5-fold and 2.4-fold, respectively). NPC enrichment resulted in significant increase in bacterial numbers at stations TM-03 $(\times 2.3)$, and TM-06 $(\times 3.3)$.

Bacterial production showed an increase of $\times 4.4$ on average (range from $\times 1.6$ to $\times 7.5$ ) in the unamended controls after $24 \mathrm{~h}$ of incubation (Table 5). The highest increase in BP relative to the control was recorded in NPC amended bottles, varying from $\times 2.0$ (station UPW) to $\times 40$ (station TM-10). Bacterial production increase relative to the control varied from $\times 0.9$ to $\times 4.6$ in $\mathrm{P}$, from $\times 0.7$ to $\times$ 2.1 in $\mathrm{N}$, and from $\times 0.7$ to $\times 4.7$ for $\mathrm{C}$ amendments.

Overall, positive effects for $\mathrm{P}$ were detected at 13 of the 18 stations, and for $\mathrm{C}$ at 5 of the 18 stations, while $\mathrm{N}$ stimulated bacterial production only at stations PRO-1 and PRO-8 $(\times 1.9$ and $\times 2.1$, respectively $)$. Finally, bacterial production was stimulated by addition of two different nutrients at three stations (PRO-1, -6 , and -8 , Table 5) and by addition of the three only at station PRO-2.

Table 5. Bacterial production in the different bioassays along longitudinal transects of TMC and PROSOPE cuise

\begin{tabular}{|c|c|c|c|c|c|c|}
\hline \multirow{3}{*}{$\begin{array}{c}\text { TMC } \\
\text { cruise }\end{array}$} & \multicolumn{2}{|c|}{ Station Depth (m) } & \multirow{2}{*}{$\begin{array}{l}\mathrm{xP} \\
3.1\end{array}$} & \multirow{2}{*}{$\begin{array}{l}\mathrm{xN} \\
0.8\end{array}$} & \multirow{2}{*}{$\frac{\mathrm{xC}}{1.1}$} & \multirow{2}{*}{$\begin{array}{r}\text { xNPC } \\
16.9\end{array}$} \\
\hline & TM-01 & 3 & & & & \\
\hline & TM-03 & 3 & 3.0 & 0.8 & 0.9 & 16.9 \\
\hline & TM-06 & 3 & 1.1 & 1.3 & 2.6 & 2.1 \\
\hline & TM-07 & 3 & 1.3 & 1.1 & 4.7 & 3.4 \\
\hline & TM-08 & 3 & 2.7 & 1.1 & 1.2 & 10.0 \\
\hline & TM-10 & 3 & 2.0 & 1.3 & 1.1 & 40.0 \\
\hline \multirow{12}{*}{$\begin{array}{c}\text { PROSOPE } \\
\text { cruise }\end{array}$} & UPW & 15 & 0.9 & 0.7 & 1.6 & 2.0 \\
\hline & PRO-1 & 11 & 1.0 & 1.9 & 1.6 & 5.2 \\
\hline & PRO-2 & 15 & 1.0 & 0.8 & 0.9 & 5.7 \\
\hline & PRO-3 & 10 & 1.4 & 1.3 & 0.9 & 4.7 \\
\hline & PRO-4 & 12 & 2.1 & 0.8 & 0.7 & 8.7 \\
\hline & PRO-5 & 11 & 4.0 & 0.8 & 0.9 & 17.7 \\
\hline & PRO-6 & 10 & 4.6 & 0.9 & 2.5 & 19.1 \\
\hline & MIO & 15 & 2.9 & 1.1 & 0.9 & 11.8 \\
\hline & PRO-7 & 14 & 1.8 & 1.2 & 0.8 & 7.9 \\
\hline & PRO-8 & 15 & 2.8 & 2.1 & 1.0 & 11.9 \\
\hline & PRO-9 & 15 & 3.3 & 1.1 & 0.8 & 11.1 \\
\hline & DYF & 10 & 4.3 & 0.9 & 0.9 & 13.0 \\
\hline
\end{tabular}

Bacterial production after 24 hours in $\mathrm{P}$ alone, $\mathrm{N}$ alone, $\mathrm{C}$ alone or the NPC enrichment is relative to the bacterial production after $24 \mathrm{~h}$ in the unenriched control (xP, xN, xC, xNPC, respectively). P: addition of 0.25 $\mu \mathrm{M}$ SRP, N:addition of $2 \mu \mathrm{M}$ nitrate, C: addition of $10 \mu \mathrm{M}$ C-glucose, NPC: addition of the three. 


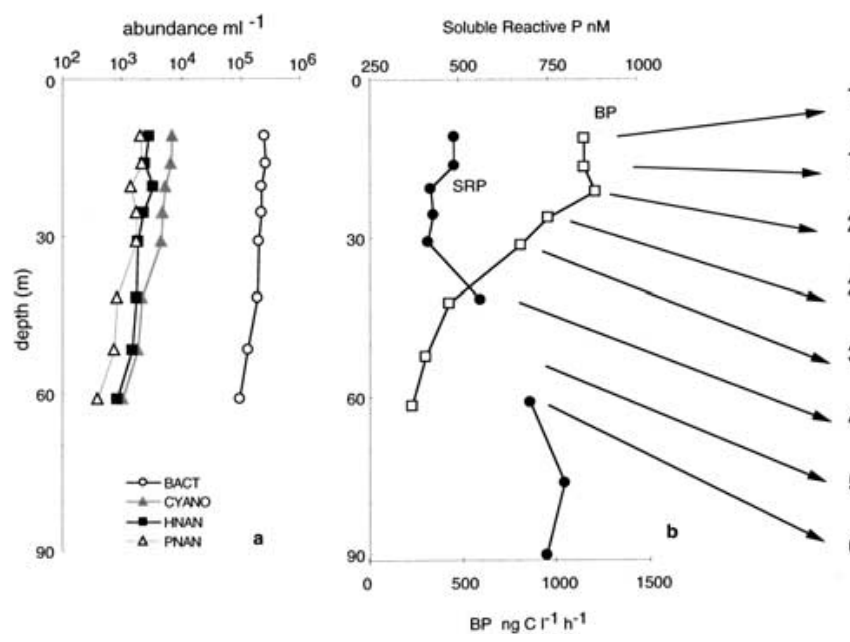

Vertical Trends. At UPW station, the mixed layer extended to $5 \mathrm{~m}$ depth, the $1 \%$ light penetration depth was at $61 \mathrm{~m}$, and the chlorophyll maximum was at $10 \mathrm{~m}$. Soluble reactive phosphorus was detectable at all depths, ranging from 0.48 to $0.79 \mu \mathrm{M}$ (mean $0.57 \pm 0.16 \mu \mathrm{M}$, Fig. 3). While bacterial abundance was relatively constant with depth, bacterial production decreased below $20 \mathrm{~m}$ depth. Organic carbon addition stimulated bacterial production at all depths. Bacterial production increased following $\mathrm{C}$ and NPC additions, and ranged from $\times 1.4$ to $\times 4.1$ and from $\times$ 1.6 to $\times 2.6$ relative to the control, respectively (Fig. 3 ).

At MIO station the mixed layer extended to $30 \mathrm{~m}$ depth, the $1 \%$ light penetration depth was at $131 \mathrm{~m}$, and the chlorophyll maximum was at $95 \mathrm{~m}$. Bacterial production

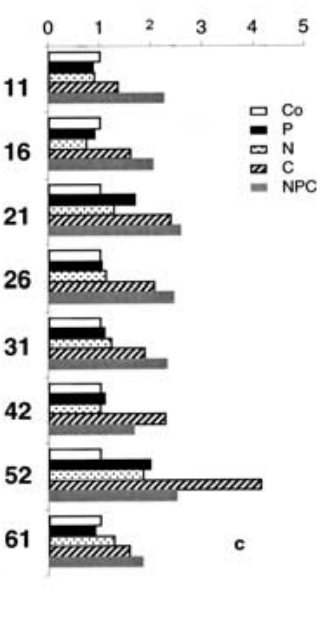

Fig. 3. Depth profiles of station UPW. (a) Abundance of heterotrophic bacteria (BACT), Synechococcus-like cyanobacteria (CYANO), heterotrophic nanoflagellates (HNAN), and autotrophic nanoflagellates (PNAN). (b) Soluble reactive phosphorus (SRP) and bacterial production (BP). (c) Bacterial production response in bioassays relative to the control, after $24 \mathrm{~h}$ incubation. Co: control, P: phosphorus enriched, $\mathrm{N}$ : nitrate enriched, C: glucose enriched, NPC: threefold enrichment. The results are normalized to the control, with values for Co set to 1 .

values at this station were low and decreased with depth. Soluble reactive $\mathrm{P}$ was undetectable in the surface and increased slowly with depth $(50 \mathrm{nM}$ concentration at 171 $\mathrm{m}$, Fig. 4). Minimum values of turnover time of alkaline phosphatase were detected in surface layers $(25 \mathrm{~h})$ and increased with depth.

At DYF station the mixed layer extended to $20 \mathrm{~m}$ depth, the $1 \%$ light penetration depth was at $70 \mathrm{~m}$, and the chlorophyll maximum was at $45 \mathrm{~m}$. Bacterial production was slightly higher at station DYF compared to MIO (Table 2) and showed a maximum within the chlorophyll maximum (Fig. 5). Soluble reactive $P$ was undetectable in the surface and increased sharply around $60 \mathrm{~m}$ depth. The AP turnover time was minimum in the surface and in-

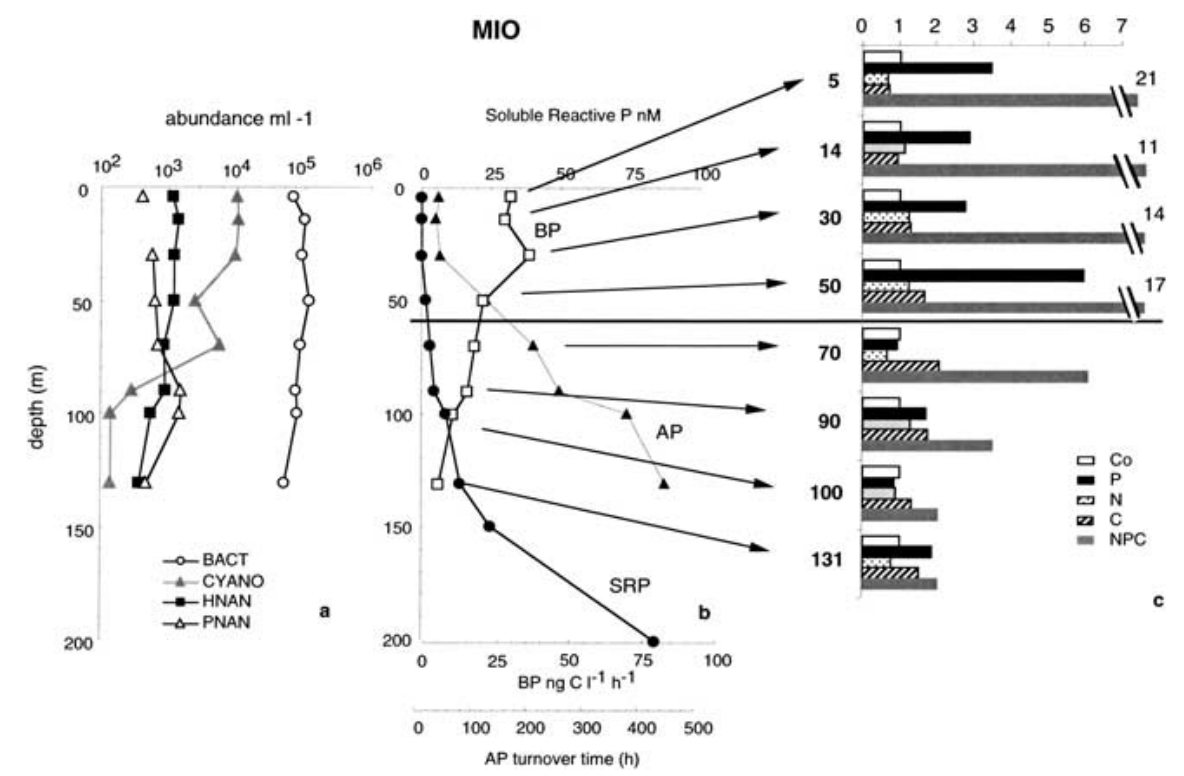

Fig. 4. Depth profiles of station MIO. Legend as in Fig. 3 except that the vertical profile of the AP turnover time is also plotted. 


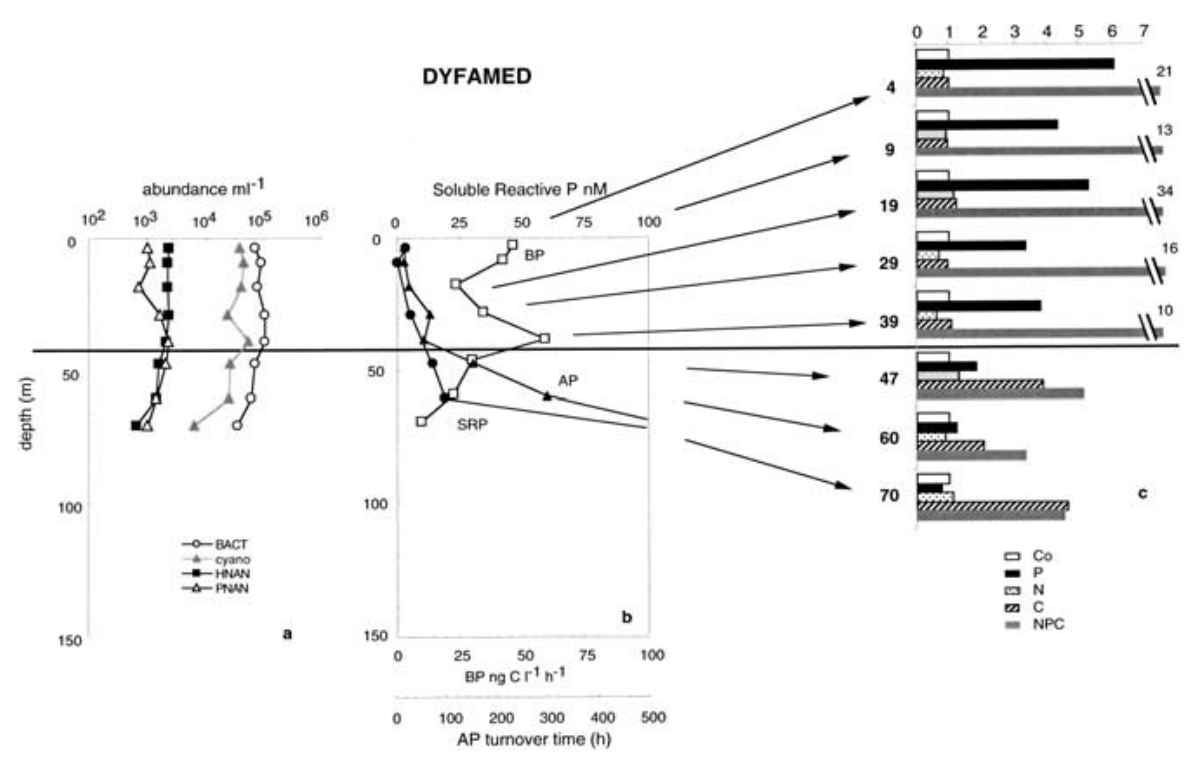

Fig. 5. Depth profiles of station DYF. Legend as in Fig. 3 except that the vertical profile of the AP turnover time is also plotted. creased with depth, but this increase was sharper and occured at a shallower depth than at the MIO station.

At stations MIO and DYF, addition of $\mathrm{P}$ alone increased bacterial production in the surface layer (Figs. 4 and 5) and glucose addition stimulated bacterial production in deeper layers (Figs. 4 and 5). At both stations DYF and MIO, the depth of transition from phosphorus to carbon limitation for bacterial production coincided with a significant increase in AP turnover time (more than $100 \mathrm{~h}$ ) and was shallower than the depth for significant soluble reactive $\mathrm{P}$ increase (Figs. 4 and 5).

Bacterial production increase, relative to the control, following NPC additions were generally higher at stations MIO and DYF than at station UPW (Figs. 3, 4, 5). This increase was particularly important for the upper layers were addition of $\mathrm{P}$ alone stimulated bacterial production.

On vertical profiles, we did not perform concentration kinetics measurements. Estimates of $\mathrm{Vm}$ were determined using Eq. (2) and assuming constant values for $\mathrm{K}+\mathrm{Sn}$. The latter assumption was reasonable as results from surface samples along the horizontal transect, where the enzymatic properties of alkaline phosphatase activity were measured, showed that turnover time and Vm varied to a wider extent than $\mathrm{K}+\mathrm{Sn}$. The two sets of $\mathrm{K}+\mathrm{Sn}$ values obtained along the horizontal transect $(96 \pm 13$ and $183 \pm 20 \mathrm{nM}$ ) corresponded to $\mathrm{C}$ and $\mathrm{P}$ limitation of bacterial production, respectively, as revealed from enrichment experiments (see above, Table 2 and Table 4). We thus extrapolated Vm of AP in depth profiles from Eq (2), with a constant $\mathrm{K}+\mathrm{Sn}$ value of $96 \mathrm{nM}$ for depths where bacterial production was stimulated by $P$ additions, and a value of $183 \mathrm{nM}$ for depths where bacterial production was stimulated by glucose. Based on these assumptions, Vm of AP decreased with depth, from $3 \mathrm{nM} \mathrm{h}^{-1}$ at $5 \mathrm{~m}$ to $0.42 \mathrm{nM} \mathrm{h}^{-1}$ at $130 \mathrm{~m}$ at station MIO and from 6 $\mathrm{nM} \mathrm{h}^{-1}$ at $5 \mathrm{~m}$ to $0.07 \mathrm{nM} \mathrm{h}^{-1}$ at $70 \mathrm{~m}$ at station DYF.

\section{Effects of Nutrient and Glucose Amendments on Ectoenzymatic} Activities and Utilization of Amino Acids

Potential ectoaminopeptidase activities measured after $24 \mathrm{~h}$ in enriched and control bottles ranged from 4 to 264 nmol L ${ }^{-1} \mathrm{~h}^{-1}$. Results at stations TM-03, TM-07, and TM08 suggested that addition of the limiting factor had a synchronous stimulating effect on bacterial production and ectoaminopeptidase activity. However, this was not the case at stations TM-06 and TM-10 (Figs. 6a, 6b). Potential assimilation rates of amino acids after $24 \mathrm{~h}$ in enriched and control bottles ranged from 0.5 to $45 \mathrm{nmol} \mathrm{L}^{-1}$ $\mathrm{h}^{-1}$. Amino acid assimilation (relative to the control) followed the same trend as bacterial production: $\mathrm{P}$ stimulation at stations TM-03, -08 , and -10 and $C$ stimulation at station TM-06 and TM-07 (Figs. 6a, 6c). Respiration percentages of amino acids decreased in all the NPC amended bottles compared to those obtained in the unamended control (Fig. 7). Moreover, respiration percentage of amino acids decreased in response to the same factors limiting bacterial production: i.e., at TM-06 and TM-07, it decreased in $\mathrm{C}$ amended bottles and at TM-03, TM-08, TM-10 in $\mathrm{P}$ amended bottles.

The ratios of potential ectoaminopeptidase activity to bacterial production (PEA/BP) and potential amino acid assimilation rates to bacterial production $(\mathrm{PAA} / \mathrm{BP})$ were 


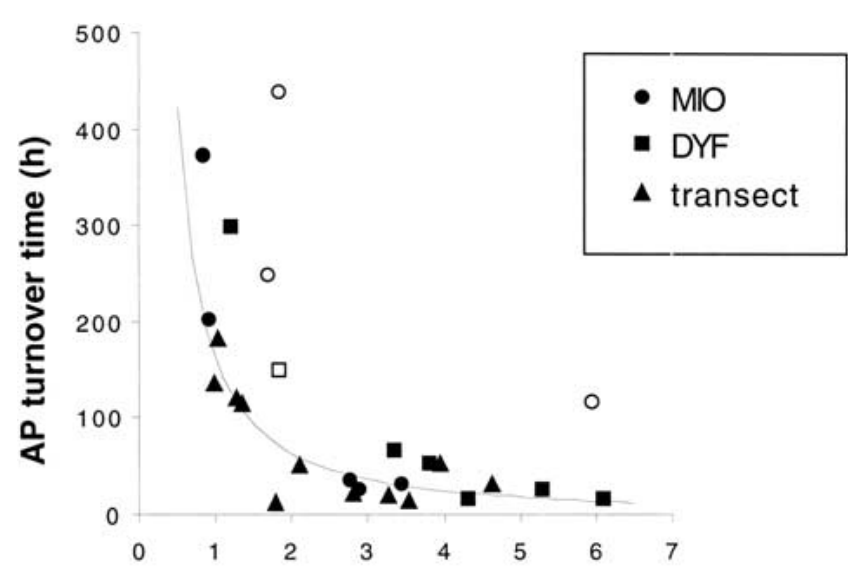

BP increase after $\mathbf{P}$ amendments

Fig. 9. Relationships between turnover time of alkaline phosphatase (AP turnover time) and bacterial production in $\mathrm{P}$ amended bottles relative to the control (BP increase after $\mathrm{P}$ amendments). Open symbols coincide with bioassays situations where bacterial production increased both after addition of $\mathrm{P}$ alone and $\mathrm{C}$ alone. The relationship represented was computed excluding these double limitation cases: $y=163 \times^{-1.37}, r^{2}=0.64$, $\mathrm{n}=22$.

bacterial production in $\mathrm{P}$ and $\mathrm{C}$ amended flasks (MIO profile: $50 \mathrm{~m}, 90 \mathrm{~m}$, and $130 \mathrm{~m}$; DYF profile: $50 \mathrm{~m}$ ) are outliers of the relationship (Fig. 9). Excluding these outliers, the significance of the regression increased $\left(r^{2}=0.64, n=22\right)$.

When $\mathrm{P}$ stimulated bacterial production (Fig. 6a), AP activity to $\mathrm{BP}$ ratios (relative to the control) were severely reduced in $\mathrm{P}$ and in NPC enrichments (TM-03, TM-08, TM-10, Fig. 8c). In contrast, when bacterial production was stimulated by glucose (TM-06, TM-07, Fig. 6a), this ratio did not decrease or decreased to a lesser degree in $\mathrm{P}$ and NPC amended bottles (Fig. 8c).

\section{Discussion}

\section{A Gradation in P Limitation?}

A positive relationship between integrated soluble reactive $\mathrm{P}$ and integrated bacterial production was obtained across the Mediterranean Sea. This relationship could be simply explained by decreasing primary production (i.e., the main source of organic carbon for heterotrophic bacteria in the open sea) related to phosphorus deficiency. However, the enrichment experiments confirmed that bacterial production in the surface layer of the Mediterranean Sea appeared to be primarily controlled by phosphorus and secondarily by carbon during the stratification period (summer and autumn). Thus, the present results confirm that phosphorus limitation of bacterioplankton is a generalized phenomenon in the Mediterranean sea, as has been hypothesized from scattered data collected at selected Mediterranean sites [6, 36, 45]. Most of the studies dealing with alkaline phosphatase activity were conducted in freshwater eutrophic conditions, e.g., [8, 41], whereas data in marine oligotrophic environments are scarce [4, $10,36]$. With a set of concentrations of 10-1000 nM MUF$\mathrm{P}$, Cotner et al. [10] determined maximum rates of alkaline phosphatase (AP) activity from 1.39 to $2.70 \mathrm{nmol} \mathrm{L}^{-1} \mathrm{~h}^{-1}$ in the upper $80 \mathrm{~m}$ in the Sargasso Sea in spring and summer. These values are of the same range as those found in this study under P limitation conditions (Table 4). In the Bay of Villefranche in summer Thingstad et al. [36] found that the maximum rate of AP was $28 \mathrm{nmol} \mathrm{L}^{-1}$ $\mathrm{h}^{-1}$, i.e., two fold higher than our greatest value $(12 \mathrm{nmol}$ $\left.\mathrm{L}^{-1} \mathrm{~h}^{-1}\right)$.

It is known that both phytoplankton and heterotrophic bacteria contribute to AP activity $[8,16]$. Indeed, in surface waters of station DYF, $47 \%$ of the AP activity and $62 \%$ of the bacterial production were associated with the $>0.6$ $\mu \mathrm{m}$ fraction. In order to consider both populations and compare different situations, maximum rates of AP are generally related to particulate organic phosphorus (POP) concentration [10, 36]. Particulate organic phosphorus was determined only during the September cruise [25]. In surface samples taken along the transect, ratios of $\mathrm{Vm}$ of alkaline phosphatase to particulate organic phosphorus (VmAP / POP) ranged from 0.11 to $0.68 \mathrm{~h}^{-1}$ in conditions of P-limitation and from 0.003 to $0.03 \mathrm{~h}^{-1}$ in conditions of C-limitation. Along the depth profiles, they fell in the same range as those measured along the transect, ranging from 0.05 to $0.67 \mathrm{~h}^{-1}$ in the upper layers where bacterial $\mathrm{P}$ limitation was found. VmAP/POP ratio reached a maximum of $0.45-0.65 \mathrm{~h}^{-1}$. These values are similar to those obtained in conditions of $\mathrm{P}$ limitation in Villefranche, 30 miles further north of station DYF in June $\left(0.6 \mathrm{~h}^{-1}[36]\right)$, and in the Sargasso Sea in spring and summer (0.3 and $0.35 \mathrm{~h}^{-1}$, respectively [10]).

In cases of bacterial $\mathrm{P}$ limitation, the ratio of alkaline phosphatase activity to bacterial production (AP / BP ratio) was strongly reduced after $\mathrm{P}$ amendments as a logical consequence of physiological (presence of excess phosphate, the by-product of phosphatase) and genetic regulation (inducible phosphatase). Surprisingly, this ratio was not always reduced after $\mathrm{P}$ additions when carbon was limiting bacterial production. In this case, bacterial 
production and alkaline phosphatase activity could be maintained because hydrolysis of organophosphoric compounds also provided organic carbon sources. The latter process has been hypothesized for deep oceanic waters [18] and freshwater [8].

The stimulation of bacterial production by a factor $\times$ 1.4 relative to the control after $24 \mathrm{~h}$ of incubation appeared to be the threshold of a significant positive effect of amendments on bacterial activity and was consistent with low turnover times of AP (Fig. 9). Our tests of reproducibility were $17 \%$ on average, which is similar to other studies: $15 \%$ [45] and 12\% [37]. However, the comparison of bacterial production between an amended flask and the control is sometimes difficult due to variable responses of bacterial production in the unamended control itself, which are not clearly understood [28, 32, 45]. The trend that we observed in vertical profiles was that the largest increases in the unamended controls were obtained in the deepest part of the vertical profiles where bacterial production to bacterial biomass ratios were lowest. This result suggests that the inactive fractions of the bacterial community react rapidly to confinement. On the contrary, in the upwelling station (UPW) where this ratio was high, bacteria reacted to a much lesser degree to confinement.

Thus, we think that the absence of a clear gradient in $\mathrm{P}$ limitation is probably due to the above mentioned sources of variability during enrichment experiments. However, from the relationship between increase of bacterial production after $24 \mathrm{~h}$ of $\mathrm{P}$ addition and turnover time of AP (Fig. 9), two interesting points emerged: i) turnover times of AP less than $100 \mathrm{~h}$, associated with a minimum of $\times 1.5$ to $\times 2$ increase of bacterial production relative to the control in $\mathrm{P}$ amended bioassays, indicated $\mathrm{P}$ limited bacteria and ii) turnover times greater than $100 \mathrm{~h}$ corresponded to an insignificant bacterial growth following $\mathrm{P}$ amendments indicating no $\mathrm{P}$ limitation.

\section{Switch from $P$ to $C$ limitation of bacterial production with depth}

Studies focusing on factors limiting bacterial production along depth profiles are scarce. In the Gulf of Mexico, Skoog et al. [33] reported that $\mathrm{N}$ limitation of bacterial activity could occur only in the vicinity of the chlorophyll maximum. Gurung and Urabe [15] observed P limitation in surface waters of Lake Biwa, and argued that temperature limited bacterial growth at greater depths. At both DYF (western Mediterranean) and MIO (eastern Mediterranean) profiles, the turnover time of alkaline phso- phatase increased with depth. Moreover, at station DYF, bacteria switched from phosphorus to carbon limitation at around $50 \mathrm{~m}$. At station MIO, however, the switch was not very clear. Although $\mathrm{P}$ limitation was detected at the surface, and carbon limitation below $40 \mathrm{~m}$, we observed that at 50,90 , and $130 \mathrm{~m}$ bacterial production increased after both $\mathrm{P}$ alone and $\mathrm{C}$ alone enrichments. Furthermore at station MIO, at the depths where $\mathrm{C}$ limitation was found, the ratio of maximum rates of alkaline phosphatase to particulate organic phosphorus (VmAP/POP) were on average higher $\left(0.075\right.$ to $\left.0.1 \mathrm{~h}^{-1}\right)$ than those measured at the $\mathrm{C}$ limited depths of station DYF (0.006-0.056 $\left.\mathrm{h}^{-1}\right)$. These two observations suggest that the $\mathrm{C}$ limited bacteria below $40 \mathrm{~m}$ at station MIO were also still P limited. Modest stimulations of bacterial growth after addition of nutrients alone or glucose alone were also reported by Felip et al. [12] in eutrophic lakes, and these authors suggested that, at in situ conditions, both nutrients and organic carbon might limit bacterial growth. Theoretically, a real colimitation of heterotrophic bacteria by $\mathrm{P}$ and $\mathrm{C}$ (i.e., the same bacteria are limited both in $\mathrm{C}$ and $\mathrm{P}$ ) bacterial production should be stimulated in $\mathrm{PC}$ enrichments, but not in $\mathrm{P}$ alone and $\mathrm{C}$ alone. Some possible explanations are as follows:

The increase in leucine incorporation rates in $\mathrm{P}$ amended bottles could be due to both heterotrophic bacteria and cyanobacteria, because cyanobacteria can assimilate leucine at low concentrations [19]. However, this explanation is unlikely in the Mediterranean, where Synechococcus-like cells, which are known for their low capability of leucine incorporation [19], dominated the cyanobacterial populations. In fact, applying the maximal rate of leucine incorporation reported in Kamjunke and Jahnichen [19], i.e., $37 \mu \mathrm{mol} \mathrm{leu}(\mathrm{g} \mathrm{chl} a)^{-1} \mathrm{~h}^{-1}$ to the maximum Synechococcus concentration observed during our study (station DYF, $27 \times 10^{3}$ cyano $\mathrm{ml}^{-1}$ ), leucine incorporation by Synechococcus would represent only $1.8 \%$ of the total incorporation rate in $\mathrm{P}$-amended bottles.

Another explanation could be related to phytoplankton-bacteria interactions during the bioassays. $\mathrm{P}$ addition alone may stimulate both $\mathrm{P}$ limited autotrophs and heterotrophic bacteria. The latter may be stimulated because, as dissolved organic carbon due to sloppy feeding, lysis, and excretion by phytoplankton increases, labile carbon becomes more available to bacteria. In contrast, glucose addition alone can stimulate only heterotrophic bacteria. In this case, glucose addition may shift the competition between phytoplankton and heterotrophic bacteria for $\mathrm{P}$ in 
favor of bacteria. Consequently, stimulation of bacterial production by addition of $\mathrm{P}$ alone or $\mathrm{C}$ alone is possible even if heterotrophic bacteria are under $\mathrm{P}$ and $\mathrm{C}$ colimitation conditions. At least, the two types of bacterial populations (one P limited, one C limited) could coexist, as models allowing such coexistence can now be constructed (Thingstad, pers. comm).

\section{Effect of Enrichment on Ectoaminopeptidase Activity and Utilization of Amino Acids}

Potential ectoaminopeptidase activity and potential assimilation rates of amino acids behaved like bacterial production after enrichments. Ratios of these activities to bacterial production, (PEA/BP and PAA/BP) did not differ more than 2-fold from those obtained for the unamended control (Fig. 8), eventhough bacterial production reponse was usually much greater (in NPC amended bottles, bacterial production relative to the control increased up to $\times$ 40; Fig. 6).

Changes within these ratios are also due to probable changes in energy requirements and/or changes of biochemical pathways induced by added substrate or nutrients. For example, when the factor limiting bacterial production was carbon, amino acid respiration percentages decreased in C and NPC amended flasks (stations TM-6 and TM-7, Fig. 7). Glucose is known to support a large fraction of the bacterial carbon requirement and is also an important energy source [29]. Consequently, bacteria used glucose to restore their energetic capacity and thus the percentage of respired amino acids was reduced, since amino acids could be assimilated directly into cellular constituents $[9,14]$.

When the factor limiting bacterial production was phosphorus, $\mathrm{P}$ addition apparently favored bacterial populations adapted to use amino acids at high concentrations (i.e., PAA/BP ratios increased, stations TM-3 and TM-8, Fig. $8 \mathrm{~b})$, whereas the potential to degrade proteins was more or less maintained (Fig. 8a). Under phosphorus limitation, populations favored after $\mathrm{P}$ amendments are thus, those adapted to rapidly use the pool of amino acids present. Additionally, the percentage of respiration of amino acids decreased after addition of $\mathrm{P}$ when phosphate limited bacterial production (station TM-3, TM-8, and TM-10). Indeed, it has been previously shown that bacterial growth efficiency decreases with nutrient limitation, both experimentally and in situ $[23,37,46]$. Our results on respiration percentage of amino acids suggest that both glucose and phosphorus limitation induced an energy limitation [5, 21] within bacterial communities in the Mediterranean.

Phosphorus limitation of bacterioplankton production was widespread in the surface layers of the Mediterranean Sea in summer and autumn. Along depth profiles, carbon limitation and/or phosphorus and carbon colimitation were observed below analytical detection limits of soluble reactive $\mathrm{P}$. A future challenge is to produce $\mathrm{P}$ budgets in the water column, through estimates of size-class components of particulate $\mathrm{P}$, dissolved organic $\mathrm{P}$, soluble reactive $\mathrm{P}$, and uptake and regeneration of $\mathrm{P}$. This budget would help to clarify interactions between $\mathrm{C}$ and $\mathrm{P}$ cycles, and this task is currently in progress.

\section{Acknowledgments}

This study was supported by the EEC MATER Project (MAST 3, PL 95-0401) and the French PROOF PROSOPE Program. We are indebted to the coordinators of the cruises, V. Likousis and H. Claustre. We thank D. Tailliez for help with Fig. 1, and E. Krasakopoulou for nutrient analysis during the TMC cruise. We acknowledge K. Pagou, O. Gotsis, and J. Ras for providing unpublished chlorophyll data, and F. Thingstad, K. Mopper, and two referees for comments on this manuscript.

\section{References}

1. Azam F (1998) Microbial control of oceanic carbon flux: The plot thickens. Science 280:694-696

2. Belviso S, Claustre H, Marty J-C (2001) Evaluation of the utility of chemotaxonomic-pigments as a surrogate for particulate DMSP. Limnol Oceanogr 6:989-995

3. Bianchi M, Turley C, Van Wambeke F, Stutt E, Christaki U, Psara S, Conan P (1996) A first and preliminary description of a relationships between the cycling of the primary production by bacteria in the photic zone and the extent of particles flux measured during the MTP pilot phase. Mediterranean Target Project News :8-9

4. Caron F, Lin Lim E, Sanders RW, Dennet MR, Berninger UG (2000) Responses of bacterioplankton and phytoplankton to organic carbon and inorganic nutrient additions in contrasting oceanic ecosystems. Aquat Microb Ecol 22:175184

5. Cherrier J, Bauer JE, Druffel ER (1996) Utilization and turnover of labile dissolved organic matter by bacterial heterotrophs in eastern North Pacific surface waters. Mar Ecol Prog Ser 139:267-279

6. Christaki U, Van Wambeke F, Dolan JR (1999) Nanoflagellates (mixotrophs, heterotrophs and autotrophs) in the oligotrophic Eastern Mediterranean: Standing stocks, bacte- 
rivory and relationships with bacterial production. Mar Ecol Prog Ser 187:297-307

7. Christaki U, Van Wambeke F, Giannakourou A, Gregori G (2001) Nanoflagellate predation on auto- and heterotrophic picoplankton in the oligotrophic Mediterranean Sea. J Plankt Res 23:1297-1310

8. Chrost RJ, Overbeck J (1987) Kinetics of alkaline phosphatase activity and phosphorus availability for phytoplankton and bacterioplankton in lake Plubsee (North German eutrophic lake). Microb Ecol 13:229-248

9. Church M, Hutchins D, Ducklow H (2000) Limitation of bacterial growth by dissolved organic matter and iron in the Southern Ocean. Appl Environ Microbiol 66:455-466

10. Cotner J, Ammermann J, Peele E, Bentzenv E (1997) Phosphorus-limited bacterioplankton growth in the Sargasso Sea. Aquat Microb Ecol 13:141-149

11. Dolan JR, Vidussi F, Claustre H (1999) Planktonic ciliates in the Mediterranean Sea: longitudinal trends. Deep-Sea Res I 46:2025-2039

12. Felip M, Pace ML, Cole JJ (1996) Regulation of planktonic bacterial growth rates: The effects of temperature and ressources. Microb Ecol 31:15-28

13. Garabétian F (1991) ${ }^{14} \mathrm{C}$-glucose uptake and ${ }^{14} \mathrm{C}-\mathrm{CO}_{2}$ production in surface microlayer and surface-water samples: influence of UV and visible radiation. Mar Ecol Prog Ser 77:21-26

14. Gardner WS, Benner R, Amon RM, Cotner JB, Cavaletto JF, Johnson JR (1996) Effect of high-molecular weight dissolved organic matter on nitrogen dynamics in the Mississipi River plume. Mar Ecol Prog Ser 133:287-297

15. Gurung TB, Urabe J (1999) Temporal and vertical difference in factors limiting growth rate of heterotrophic bacteria in Lake Biwa. Microb Ecol 38:136-145

16. Hoppe HG (1986) Relations between bacterial extracellular enzyme activity and heterotrophic substrate uptake in a brackish water environment. In IFREMER (Ed) Deuxième Colloque Int. de bactériologie Marine, Brest, 1-5 Octobre 1984, Actes et Colloques 3, Ann Arbor, pp. 119-127

17. Hoppe HG (1993) Use of fluorogenic model substrates for extracellular enzyme activity measurement of bacteria. In: PF Kemp, BF Sherr, EB Sherr, JJ Cole (eds) Handbook of Methods in Aquatic Microbial Ecology. Lewis, Boca Raton, pp 423-431

18. Hoppe HG, Ullrich S (1999) Profiles of ectoenzymes in the Indian Ocean: phenomena of phoshatase activity in the mesopelagic zone. Aquat Microb Ecol 19:139-148

19. Kamjunke N, Jahnichen S (2000) Leucine incorporation by Microcystis aeruginosa. Limnol Oceanogr 45:741-743

20. Karl D, Tien G (1992) MAGIC: a sensitive and precise method for measuring dissolved phosphorus in aquatic environments. Limnol. Oceanogr. 37:583-588

21. Kirchman DL (1990) Limitation of bacterial growth by dissolved organic matter in the subarctic Pacific. Mar Ecol Prog Ser 62:47-54

22. Kirchman DL (1993) Leucine incorporation as a measure of biomass production by heterotrophic bacteria. In: PF
Kemp, BF Sherr, EB Sherr, JJ Cole (eds) Handbook of Methods in Aquatic Microbial Ecology. Lewis, Boca Raton, pp 509-512

23. Kroer N (1993) Bacterial growth efficiencies on natural dissolved organic matter. Limnol Oceanogr 38:12821290

24. Krom MD, Kress N, Brenner S, Gordon S (1991) Phosphorus limitation of primary productivity in the eastern Mediterranean Sea. Limnol Oceanogr 36:424-432

25. Moutin T, Thingstad FT, Van Wambeke F, Marie D, Claustre $\mathrm{H}$ Is the predominance of synechococcus as primary producer in the Mediterranean Sea related to phosphate uptake competition with heterotrophic bacteria? Submitted

26. Moutin T, Raimbault P (2002) Primary production, carbon export and nutrients availability in western and eastern Mediterranean Sea in early summer 1996 (MINOS cruise). J Mar Syst: in press

27. Murphy J, Riley JP (1962) A modified solution method for determination of phosphate in natural waters. Analyt Chim Acta 27:31-36

28. Pomeroy LR, Sheldon JE, Sheldon WM, Peters F (1995) Limits to growth and respiration of bacterioplankton in the Gulf of Mexico. Mar Ecol Prog Ser 117:259-268

29. Rich JH, Ducklow HW, Kirchman DL (1996) Concentration and uptake of neutral monosaccharides along $140^{\circ} \mathrm{W}$ in the equatorial Pacific: contribution of glucose to heterotrophic bacterial activity and DOM flux. Limnol Oceanogr 4:596604

30. Rivkin RB, Anderson M (1997) Inorganic nutrient limitation of oceanic bacterioplankton. Limnol Oceanogr 42:730-740

31. Sournia A (1973) La production primaire planctonique en Méditerranée-Essai de mise à jour, Newsletter of Cooperative Investigations in the Mediterranean. Monaco 5:1127

32. Sherr EB, Sherr BF, Sigmon C (1999) Activity of marine bacteria under incubated and in situ conditions. Aquat Microb Ecol 20:213-223

33. Skoog A, Biddanda B, Benner R (1999) Bacterial utilization of dissolved glucose in the upper water column of the Gulf of Mexico. Limnol Oceanogr 44:1625-1633

34. Smith DC, Azam F (1992) A simple, economical method for measuring bacterial protein synthesis rates in sea water using ${ }^{3}$ H-Leucine. Mar Microb Food Webs 6:107-114

35. Thingstad TF, Rassoulzadegan R (1995) Nutrient limitations, microbal food webs, and "biological C-pumps": suggested interactions in a P-limited Mediterranean. Mar Ecol Prog Ser 117:299-306

36. Thingstad TF, Zweifel UL, Rassoulzadegan F (1998) P limitation of heterotrophic bacteria and phytoplankton in the northwestern Mediterranean. Limnol Oceanogr 43:88-94

37. J-P Torréton, Talbot V, Garcia N (2000) Nutrient stimulation of bacterioplankton growth in Tuamotu atoll lagoons. Aquat Microb Ecol 21:125-137

38. Treguer P, Le Corre P (1975) Manuel d'analyses des sels nutritifs dans l'eau de mer (utilisation de l'Auto-Analyser II 
Technicon), 2nd ed., Laboratoire d'Océanographie chimique. Université de Bretagne Occidentale, Brest

39. Tselepides A, Zervakis V, Polychronaki T, Danovaro R, Chronis G (2000) Distribution of nutrients and particulate organic matter in relation to the prevailing hydrographic features of the Cretan Sea (NE Mediterranean). Prog Oceano 46:113-142

40. Turley C, Bianchi M, Christaki U, Conan P, Harris J, Psarra S, Ruddy G, Stutt E, Tselepides A, Van Wambeke F (2000) (2000) Relationships between primary producers and bacteria in an oligotrophic sea-the Mediterranean. Aquat Microb Ecol 183:11-18

41. Vadstein O Heterotrophic, planktonic bacteria and cycling of phosphorus. Phosphorus requirements, competitive ability and food web interactions. In: B Schink (ed) Advances in Microbial Ecology, vol 16. Kluwer Academic/Plenum, New York, pp 115-167
42. Valderrama JC (1981) The simultaneous analysis of total nitrogen and total phosphorus in natural waters. Mar Chem 10:109-122

43. Van Wambeke F, Christaki U, Bianchi M, Psarra S, Tselepides A (2000) Heterotrophic bacterial production in the Cretan Sea (NE Mediterranean). Prog Oceanogr 46:205-216

44. Vaulot D, Le Bot N, Marie D, Fukai E (1996) Effect of phosphorus on the Synechococcus cell cycle in surface Mediterranean waters during summer. Appl Environ Microbiol 62:2527-2533

45. Zohary T, Robarts RD (1998) Experimental study of microbial P-limitation in the eastern Mediterranean. Limnol Oceanogr 43:387-395

46. Zweifel UL, Norrman B, Hagström ADA (1993) Consumption of dissolved organic carbon by marine bacteria and demand for inorganic nutrients. Mar Ecol Prog Ser 101: 23-32 